\title{
Pollination and nectar production of Psittacanthus SChiedeanus (Loranthaceae) in Central VeracruZ, Mexico
}

\author{
María Magdalena Ramírez and Juan Francisco Ornelas ${ }^{1}$ \\ Departamento de Biología Evolutiva, Instituto de Ecología, A.C. \\ ${ }^{1}$ Corresponding autor: francisco.ornelas@inecol.edu.mx
}

\begin{abstract}
We assessed nectar production patterns, the breeding system, and overall pollinator dependence of Psittacanthus schiedeanus (Schlecht. \& Cham.) G.Don (Loranthaceae), a mistletoe species that blooms in the late summer of the eastern cloud forests of Mexico and whose flowers are mainly visited by hummingbirds. Despite differences in nectar production rates over the lifespan of a flower, the daily nectar secretion of 3.6-7.2 mg sugar/flower/day was high compared to other hummingbird-adapted plant species. Hand-pollination experiments showed that this plant is self-compatible, with only a slight advantage of cross- (xenogamous) and geitonogamous hand-pollinated flowers over autonomous hand-pollinated flowers. Hence, the high production of nectar by $P$. schiedeanus flowers represents an important ecosystem resource that may mediate interactions with a wide variety of floral visitors. Although $P$. schiedeanus set selfed fruits autonomously, this plant requires hummingbirds to achieve its full reproductive potential.
\end{abstract}

Key words: hummingbirds, Loranthaceae, Mexico, mistletoes, nectar production, pollination, Psittacanthus.

Resumen: Determinamos la importancia de los patrones de producción de néctar, el sistema reproductivo, y la dependencia general de un polinizador de Psittacanthus schiedeanus (Schlecht. \& Cham.) G.Don (Loranthaceae), una especie de muérdago que florece a finales del verano de los bosques de niebla en el este de México cuyas flores son visitadas principalmente por colibríes. A pesar de las diferencias en las tasas de producción de néctar a lo largo de la vida de una flor, la secreción diaria de néctar de 3.6-7.2 mg azúcar/ flor/día fue alta comparada con otras especies de plantas adaptadas a colibríes. Los experimentos de polinización manual mostraron que esta planta es autocompatible, con solo una ligera ventaja por flores manualmente cruzadas con flores de la misma planta (geitonogamia) o de una diferente (xenogamia). Entonces, la producción alta de néctar por flores de $P$. schiedeanus representa un recurso importante en el ecosistema que puede mediar interacciones con una gran variedad de visitants florales. Aunque $P$. schiedeanus forma frutos por autogamia, esta planta requiere a los colibríes para lograr su potencial reproductivo máximo.

Palabras clave: colibríes, Loranthaceae, México, muérdagos, polinización, producción de néctar, Psittacanthus.

$\mathbf{T}$ he genus Psittacanthus (Loranthaceae) is a New World aerial hemiparasite distributed from Mexico to Argentina on a wide range of angiosperm and gymnosperm hosts (Kuijt, 2009). In contrast to other mistletoes, Psittacanthus is distinguished by its large and conspicuous-red, yellow, or orange flowers and bulky haustorial connections to the host trees, and by large fruits which lack endosperm (Cházaro and Oliva, 1988; Kuijt, 2009). In his recent monographic treatment of the genus, Kuijt (2009) considered 119 species in the genus, 51 of which are newly described. In his monograph, Kuijt (2009) recognized 11 species of Psittacanthus for Mexico: P. angustifolius Kuijt, P. auriculatus Eichler, P. breedlovei Kuijt, P. calyculatus G. Don, P. macrantherus Eichler, P. mayanus Standl. \& Steyerm., P. palmeri (Watson) Barlow \& Wiens, P. ramiflorus G. Don, P. rhynchan- thus (Benth.) Kuijt, P. schiedeanus (Schlecht. \& Cham.) G. Don, and P. sonorae (Watson) Kuijt. Although Psittacanthus is distributed throughout Mexico (Cházaro and Oliva, 1988; Vázquez-Collazo and Geils, 2002), it is most common in the central and southern regions ranging from sea level to 3,300 m above sea level. Parrot-flower mistletoes of the genus Psittacanthus are considered to be the most damaging pathogens to attack commercially important coniferous and other hardwood timber stands throughout Mexico (Vázquez-Collazo and Geils, 2002). More than 50 genera of angiosperms and conifers have been reported as hosts of Psittacanthus in Mexico, and several non-native plant genera (Vázquez-Collazo and Geils, 2002). The most common Psittacanthus species reported on conifers (Pinus and Abies) are P. angustifolius and P. macrantherus (Kuijt, 1987, 
2009; Mathiasen et al., 2007). In arid environments and lowland, tropical deciduous forests, $P$. sonorae (Sonora and Baja California), P. rhynchanthus (Balsas drainage), and P. palmeri (subtropical Central Plateau) parasitize almost exclusively Bursera species, and $P$. auriculatus (TehuacánCuicatlán arid region) and $P$. breedlovei (Chiapan Central Depression) are most commonly found on Acacia species (Kuijt, 2009). However, most Psittacanthus species often use more than one species of host. Despite their negative economic impact, parrot-flower mistletoes are ecologically important in forest ecosystems as they provide food, cover and nesting sites for a variety of birds, mammals and insects (reviewed in Watson, 2001; Mathiasen et al., 2008).

Although mistletoe plants are parasites of trees, most are not damaging pathogens and do not impact economically valuable crops and forest products but actually play key roles in forest ecosystems associated with these parasitic flowering plants (reviewed in Watson, 2001; Mathiasen et al., 2008). Coevolutionary relationships with birds (involving pollination and seed dispersal) have fueled several adaptive radiations, thus producing one of the most diverse and fascinating life forms on our planet. The coevolution of mistletoes with their avian vectors has resulted in elaborate seed dispersal mechanisms and in attractive and nutritious fruits that provide valuable food for many bird species throughout the world. Approximately 90 bird species from 10 families are considered mistletoe fruit specialists, exhibiting a range of behavioral and morphological adaptations to their narrow diet (Mathiasen et al., 2008 and references therein). Elaborate pollination mechanisms involving birds have also evolved in some of Loranthaceae species (e.g., Ladley and Kelly, 1995; Ladley et al., 1997). Many tropical and subtropical mistletoes in Loranthaceae have large, colorful flowers borne in groups that produce large amounts of sugar-rich nectar that attract avian pollinators. However, the basic reproductive biology of most Neotropical Loranthaceae, and specifically Psittacanthus species, has not been described. In Tristerix corymbosus, Aizen (2005) reported that hummingbird cross-pollination had a slight advantage with respect to self hand-pollination in a population near Bariloche, Argentina. The only detailed study of hummingbird pollination in Psittacanthus has been recently accounted for $P$. calyculatus in Tlaxcala, Mexico (Azpeitia and Lara, 2006). They found that anthesis in the species is initiated by anther dehiscence, and stigma receptivity followed only $24 \mathrm{~h}$ later. The flowering period lasts from July to November in the studied area, roughly corresponding to the local mild and humid period. As in T. corymbosus, Aspeitia and Lara (2006) found that $P$. calyculatus is predominantly an outbreeding plant, even though self-pollination can also be effective.

Here we report the results of a breeding-system study to assess the overall dependence of Psittacanthus schiedeanus on hummingbirds for pollination and sexual reproduction. If pollinator services by hummingbirds are effective and predictable, we expect an obligate dependence on hummingbirds for reproduction, and the existence of a mechanism of reproductive assurance such as facultative, autonomous self-pollination. In addition to testing for autogamous seed production and self-compatibility, we also estimated selfand cross-pollinated flowers to assess the role of outbreeding in $P$. schiedeanus, and nectar production patterns are described.

\section{Materials and methods}

Study system. Psittacanthus schiedeanus (Schlecht. \& Cham.) G.Don, parrot-flower mistletoe, is a shrubby (up to $3 \mathrm{~m}$ in height) hemiparasite distributed along the eastern rim of the Sierra Madre Oriental between 1000 to 1800 $\mathrm{m}$ above sea level in Mexico to Panama. It parasitizes tall trees in evergreen montane forests (Burger and Kuijt, 1983; Cházaro and Oliva, 1988; López de Buen et al., 2002; Kuijt, 2009). Throughout its geographic range, it parasitizes branches of more than 20 native and introduced host tree species (Cházaro and Oliva, 1988; López de Buen and Ornelas, 1999). In central Veracruz, the most severe infections occur on Liquidambar styraciflua var. mexicana (Oested.) (=macrophylla) (Altingiaceae) (López de Buen and Ornelas, 1999; López de Buen et al., 2002). Reproductive plants with terminal and secondary inflorescences can produce several hundred flower buds that differentiate and develop during June and July. The floral buds (7.5-8.5 cm long) are more or less straight, slender, slightly widening below tip. Longpedicelate (10-30 $\mathrm{mm}$ long, $n=360$, J.F. Ornelas, unpublished data) flowers are arranged in 3.5 pairs of triads with

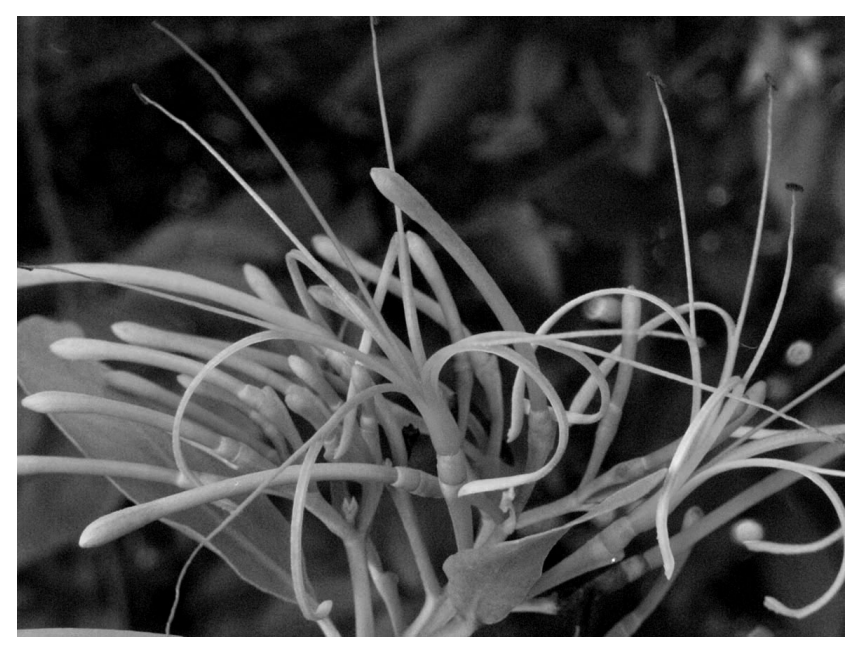

Figure 1. Typical inflorescence of Psittacanthus schiedeanus showing open flowers and floral buds at various developmental stages. Note that the petals strongly curl around and the filament holding out the anthers in all directions inserted low on the petals. Photo by Juan Francisco Ornelas. 
peduncles 1-2 cm long. Peduncle and pedicels are bright orange-red to yellow when exposed, especially in fruit (Kuijt, 2009). The flowers of $P$. schiedeanus are actinomorphic and hexamerous (Figure 1). Flowers last open c. $6 \mathrm{~d}$ in the study area. As senesces the orange-yellow flower, or parts of it, turn red. When the flower opens to near the base, the six petals strongly curl around and the filament holding out the anthers (34 mm long, $n=341$, J.F. Ornelas, unpublished data) in all directions inserted low on the petals. Flowers open to different degrees, and filament length and level of filament implantation may be related to pollination mode (figure 1). The narrow petals diverge greatly during anthesis, and no discernable floral tube $(8 \mathrm{~mm}$ long, $n=338$, J.F. Ornelas, unpublished data) is then present. The filaments are extremely long ( $71 \mathrm{~mm}$ long, $n=341$, J.F. Ornelas, unpublished data), and are similarly spread out during flowering. Several to many adjacent flowers in an inflorescence open simultaneously (Kuijt, 2009). The most common pattern in the flower color is for the proximal part of the filamentous petals to be bright orange (often brilliantly so) and the tips to be bright yellow. The brilliant hues of the hermaphroditic flowers suggest that birds, especially hummingbirds are the primary pollinators. Several hummingbird species (Campylopterus curvipennis, Amazilia beryllina, A. cyanocephala, Lampornis amethystinus, Lamprolaima rhami, Atthis heloisa), parrots (Pionus senilis), flowerpiercers (Diglossa baritula), butterflies, and bees have been observed visiting flowers of $P$. schiedeanus in the study region (López de Buen and Ornelas, 2002; J. F. Ornelas, unpublished data). Nocturnal floral visitors are not known for $P$. schiedeanus.

Flowers mature into $13.8 \times 9.5 \mathrm{~mm}$, purplish-black fleshy, lipid-rich fruits containing one seed which weight averages 335 mg (López de Buen and Ornelas, 2001). Fruit ripening occurs asynchronously from November to April. Fruits are consumed and dispersed by a variety of birds, the most frequently observed are: Bombycilla cedrorum, Ptilogonys cinereus, and Myiozetetes similis (López de Buen and Ornelas, 1999, 2001, 2002; Ramírez and Ornelas, 2009).

Study area. The study was conducted in central Veracruz, Mexico during the flowering seasons of July-August 2003 and 2004, in two cloud forest remnants located near the city of Xalapa (La Pitaya, Coatepec, $19^{\circ} 30^{\prime}$ N, 96 $6^{\circ} 57^{\prime} \mathrm{W}$, at 1381 $\mathrm{m}$ above sea level; Rancho Viejo, San Andrés Tlalnelhuayocan, $19^{\circ} 35^{\prime} \mathrm{N}, 96^{\circ} 01^{\prime} \mathrm{W}$, at $1461 \mathrm{~m}$ above sea level). The region is characterized by frequent and prolonged immersion within orographic clouds. Climate is mild and humid throughout the year with a dry-cold season from November to March. The most common trees species in the fragments are Liquidambar styraciflua var. mexicana, Quercus germana, Q. leiophylla (Fagaceae), Platanus mexicana (Platanaceae), and Acacia pennatula (Leguminosae) (López de Buen and Ornelas, 1999).
Natural patterns of nectar production. The amount of nectar secreted by a flower may not be clearly revealed when natural patterns of nectar production are measured, particularly among species that positively respond to nectar extraction by their pollinators (Ordano and Ornelas, 2004). We quantified nectar production to determine whether flowers reward pollinators equally over time and when the pollinators sought out such resources. Inflorescences of 8 mistletoes plants growing on A. pennatula were bagged in July-August 2003 with bridal netting before bud opening. Nectar was extracted the following day without removing the flowers from the plant (non-destructive method). Nectar production was measured repeatedly throughout the life of individual flowers at 24-h intervals during six days to minimize the effects of evaporation in the quantification of nectar production. Nectar volume was measured using graduated micropipettes $(10 \mu \mathrm{L})$ and a ruler. Sugar concentration (percentage sucrose) was measured with a pocket refractometer (American Optical 10431, Buffalo, New York, USA; range of concentration $0^{\circ}-50^{\circ}$ BRIX scale) and the amount of sugar produced was expressed as milligrams of sugar after Bolten et al. (1979) and Kearns and Inouye (1993). Two hundred flowers were examined.

In a different group of plants, we measured the nectar for which buds of selected inflorescences were excluded from floral visitors to let nectar accumulate. The accumulated nectar was extracted the following day after the exclusion at 0800 . The one-day sampled flowers (24-h interval of nectar accumulation) were removed from the plant after nectar measurements (destructive-method) and the same procedure was repeated on groups of flowers in which nectar was let to accumulate 2, 3, 4 and 5 days $(48,72,96$, and 120-h intervals of nectar accumulation). Nectar production was measured as described above.

Pollination experiments. To evaluate the relative importance of pollinators, the following manual-pollination experiments were performed. In mid-August 2004, we selected flowering branches of 8 reachable mistletoe plants growing on A. pennatula and recently opened flowers were individually tagged and assigned per plant the following pollination treatments. To test for within-flower, autonomous self-pollination and autogamous fruit set, we bagged the flower by enclosing the flowering branch in a pollination bag made of 1-mm tul mesh (Treatment 1: autogamy, $n=77$ flowers). To test for self-compatibility, we hand-pollinated flowers of a given flowering branch by brushing anthers from other flower of the same individual and excluded pollinators by enclosing the flowering branch as described (Treatment 2: geitonogamy, $n=85$ flowers). To test for cross-compatibility, we hand-pollinated flowers of a given flowering branch with pollen from other individuals and excluded pollinators by enclosing the flowering branch as described (Treatment 3: xenogamy, $n=93$ flowers). Finally, we assessed natural 
pollination and fruit set from a different group of flowers that remained open to pollinators (Treatment 4: open pollination, $n=81$ flowers). Hand-pollination (Treatments 2 and 3) was applied once on 3-d old flowers when stigma receptivity is higher (M. M. Ramírez, unpublished data). Two months until fruit maturation we counted the number of fruits per pollination treatment, measured with a calliper and weighted $(0.001 \mathrm{~g})$.

Statistical analyses. We used repeated-measures ANOVA to analyze plant differences regarding nectar production (volume and amount of sugar) over each flower's lifespan. The model includes the effects of days (flower age) as repeated factors (i.e. within-subject factors) and the effects of plants as between-subject factor. To evaluate the effects of flower age (day treatment) on accumulated nectar, we used nested analyses of variance (ANOVAs) with type III sum of squares on nectar volume (microliters) and sugar production (mass of sugar in milligrams). Nectar volume and total sugar produced here were intercorrelated response variables (volume vs. sugar, $r=0.32, n=202, P=0.0001$ ). Therefore, we first performed nested multivariate ANOVAs (MANOVA) incorporating these response variables. In the model, flower age was a fixed factor and plant factor was nested within flower age (day treatment). Using a MANOVA followed by univariate ANOVAs as described above, will reduce the probability of inflating the type I error rate. Nectar volume and mass of sugar data were $\log (x+1)$ transformed before statistical analyses to achieve normality, but untransformed data (mean \pm standard error) are reported in figure 2. Pollination treatment and fruit production (fruit set) were tested with a $G$-test of independence with Yates' continuity correction. We used a Fisher's exact test to test whether fruit production differed between pollination treatments (flowers excluded to pollinators, exposed to natural pollination, geitonogamy and xenogamy). All statistical analyses were run using StatView and SuperANOVA (Abacus Concepts, Inc.).

\section{Results}

Nectar replenishment rates among flowers decreased over their lifespan (repeated-measures ANOVA; flower age effect; nectar volume, $F_{5,1340}=1394.45, P=0.0001$; sugar production, $\left.F_{5,1325}=1044.03, P=0.0001\right)$. Flowers subjected to daily repeated nectar removal replenished about 2 times more nectar per day on day 1, 2 and 3 than they did from day 4 on (Figure 2a). Sugar production followed the same pattern over time described for total nectar volume (Figure $2 \mathrm{~b}$ ). Patterns of variation were also affected by plant (nectar volume, $F_{7,1340}=33.98, P=0.0001$; sugar production, $F_{7,1325}$ $=19.81, P=0.0001)$, and the plant $\times$ flower age interactions (nectar volume, $F_{35,1340}=14.69, P=0.0001$; sugar production, $F_{35,1325}=11.27, P=0.0001$ ) were also significant.

Flower age affected subsequent nectar production nega- tively in P. schiedeanus. A MANOVA showed that flower age (day treatment) significantly influenced total nectar production for both dependent variable (volume and amount of sugar, Wilks' $\left.\lambda=0.542, F_{10,412}=14.73, P=0.0001\right)$. Plant individuals (nested within day treatments) were significantly heterogeneous for the two dependent variables (Wilks' $\lambda$ $\left.=0.546, F_{52,412}=2.79, P=0.0001\right)$. Because the MANOVA was significant, we then followed with univariate ANOVAs. Daily nectar accumulation varied significantly over time, decreasing with flower age (one-way ANOVA, $F_{5,207}$ $=30.74, P=0.0001)$. Undisturbed flowers accumulate $\mathrm{c}$. 17 microliters on day 1 after $24 \mathrm{~h}$ of accumulation but decreases as they aged from day 2 on (Figure 2a) likely due to evaporation and/or reasorption. Daily sugar production also varied significantly over time (one-way ANOVA, $F_{5,207}$ $=24.05, P=0.0001$ ), decreasing with flower age. An undisturbed flower accumulates c. 2 milligrams per day on day 1 and 2 after $24-48 \mathrm{~h}$ of accumulation, but then steeply decreases from day 3 on (Figure $2 b$ ).

When flowers that experienced repeated removals are visually compared with those undisturbed flowers that accumulated nectar over time, the total amount of fluid and
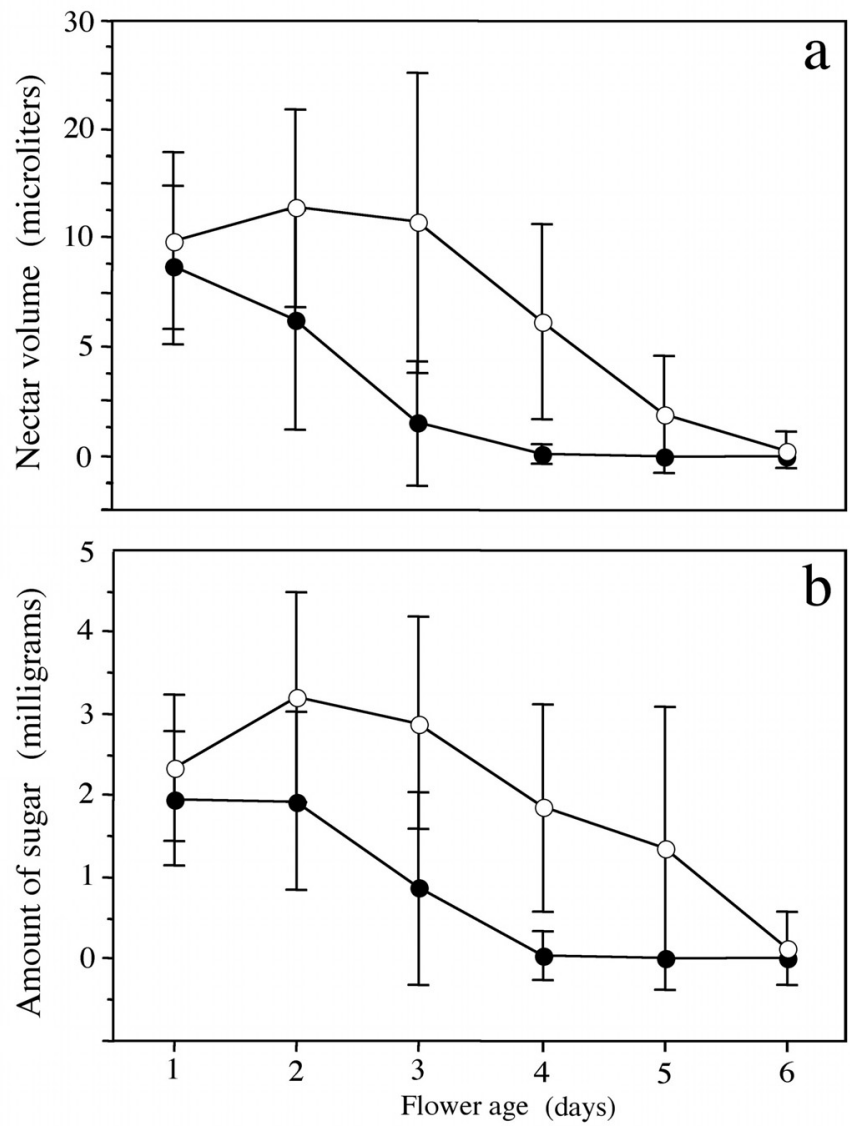

Figure 2. Cumulative nectar after repeated removals (open circles) and accumulated nectar over time (closed circles) of Psittacanthus schiedeanus flowers. Data are means \pm 1 SD. (a) Nectar volume (in microliters), (b) sugar production (in milligrams). 
Table 1. Fruit set (number of fruits / number of flowers) and fruit size in Psittacanthus schiedeanus for flowers exposed to pollination treatments. Fruit size data are means $\pm 1 \mathrm{SE}$.

\begin{tabular}{|c|c|c|c|c|c|c|}
\hline Pollination treatment & $\begin{array}{l}\text { Number of } \\
\text { flowers }\end{array}$ & $\begin{array}{l}\text { Number of } \\
\text { fruits }\end{array}$ & Fruit set & $\begin{array}{l}\text { Fruit width } \\
\qquad(\mathrm{mm})\end{array}$ & $\begin{array}{l}\text { Fruit length } \\
\qquad(\mathrm{mm})\end{array}$ & $\begin{array}{l}\text { Fruit weight } \\
\text { (g) }\end{array}$ \\
\hline Autonomous self-pollination & 77 & 14 & 0.18 & $9.19 \pm 0.2$ & $13.73 \pm 0.3$ & $0.75 \pm 0.04$ \\
\hline Geitonogamous hand-pollination & 85 & 32 & 0.38 & $9.36 \pm 0.1$ & $13.70 \pm 0.2$ & $0.71 \pm 0.03$ \\
\hline Xenogamous hand-pollination & 93 & 33 & 0.35 & $9.36 \pm 0.1$ & $13.77 \pm 0.2$ & $0.75 \pm 0.02$ \\
\hline Open pollination & 81 & 18 & 0.22 & $9.46 \pm 0.1$ & $14.01 \pm 0.3$ & $0.76 \pm 0.04$ \\
\hline
\end{tabular}

sugar secreted was markedly different between nectar treatments (Figure 2); undisturbed flowers secreted about half the amount of fluid or sugar secreted by flowers subjected to repeated nectar removal (Figure 2).

Flowers from all pollination treatments set fruit. Outcrossed (xenogamy), hand-pollinated flowers set fruits as well as flowers exposed to geitonogamous crosses, natural pollination (control), and flowers excluded from pollination (autogamy) (Table 1). However, fruit production was not independent of pollination treatment $(G=11.36$, df $=3, P<$ 0.01 ). Fruit set (in relation to flower number) was somewhat higher in geitonogamous hand-pollinated flowers $(37.6 \%)$ than xenogamous hand-pollinated flowers $(35.5 \%)$, flowers open to natural pollination $(22.2 \%)$ and excluded, autogamous flowers $(18.2 \%)$. Fruit set was significantly higher $(P$ $=0.044$ in a Fisher's exact test) in geitonogamous flowers than in autogamous flowers; fruit set in xenogamous flowers differed marginally from autogamous flowers $(P=0.06)$. There were no significant differences among fruit set in the remaining comparisons $(P>0.1$ in Fisher's exact tests; see also Table 1). Because hand self-pollinated flowers set almost as many as cross-pollinated ( $P=0.88$ in a Fisher's exact test), we consider $P$. schiedeanus to be fully self-compatible. However, open- and hand-pollinated flowers set more fruits than autonomous self-pollinated flowers. Thus, although $P$. schiedeanus set selfed fruits autonomously, this plant requires hummingbirds to achieve its full reproductive potential. Lastly, no significant differences in fruit size were observed among treatments $(P>0.1$, Table 1$)$.

\section{Discussion}

We used nectar production after repeated removal as a nectar sampling technique to investigate maximum nectar output to floral visitors across the flower's lifespan (see also Hernández-Conrique et al., 2007). By repeatedly removing nectar, we may have stimulated replenishment of the fluid and therefore natural secretion patterns may have been obscured. However, nectar accumulation data avoid this problem but underestimates the capacity of the plants to respond to repeated nectar removal by floral visitors (Ordano and Ornelas, 2004). By emptying all nectar from the same set of flowers at daily intervals, we minimized the effects of evaporation observed among flowers left to accumulate nectar, so it is unlikely that variation in nectar replenishment rates is due to microclimate differences over the flower's lifespan. The result of decreased nectar accumulation over time ties in well with the result that hummingbird-adapted flowers do usually increased total nectar production when drained repeatedly. In $P$. schiedeanus, the magnitude of the response to the removal effect can be explained in part by the large number of floral visitors. Hence, the high production of nectar by $P$. schiedeanus flowers (and the number of flowers produced per plant) represents an important ecosystem resource that may mediate interactions with a wide variety of plant visitors, depending on seasonal and spatial availability. The sugar totals (3.6-7.2 mg sugar per flower per day) are high compared to values of other hummingbird-visited species (reviewed in Ornelas et al., 2007). For hummingbirds, $P$. schiedeanus represents a rich resource compared to other hummingbird-pollinated flowers of the cloud forests in the region (e.g., Lara and Ornelas, 2003; Ornelas et al., 2004), other late summer flowers in this region (Lara and Ornelas, 2002), flowers from other Psittacanthus species (Azpeitia and Lara, 2006), or from other hummingbird-adapted species (Hernández-Conrique et al., 2007; Lara and Ornelas, 2008). Although Neotropical mistletoe flowers are highly variable in terms of nectar production, values for $P$. schiedeanus are high to median for Neotropical mistletoe flowers (Cruden et al., 1983; Opler, 1983; Stiles and Freeman, 1993; Tadey and Aizen, 2001; Ornelas et al., 2007). Thus, the high nectar production rates, the large floral display (number of flowers open per day and number of inflorescences per plant), flower longevity, and the extended flowering time (3 mo) suggest that allocation to pollinator attraction is large in $P$. schiedeanus.

Autonomous, within-flower self-pollination has been proposed as a feature characterizing the breeding system of many Loranthaceae (Aizen, 2005; Azpeitia and Lara, 2006). Despite self-compatibility, P. schiedeanus exhibits a limited capacity for self-pollination, about one third of full seed set. Therefore, this plant requires the service of its hummingbird pollinators to achieve full reproductive success. Although spatial separation of androecium and gynoecium is characteristic of many bird-pollinated members of Loranthaceae (e.g., Ladley et al., 1997), there is no particular mechanism 
promoting autonomous self-pollination that we have detected in P. schiedeanus. The fitness consequences of selffertilization are largely determined by how self-pollination occurs in $P$. schiedeanus. Within-flower self-pollination (autogamy) may be advantageous, since it can provide reproductive assurance under conditions of pollinator scarcity without much seed or pollen discounting (see also Aizen, 2005). In contrast, between-flower self-pollination (geitonogamy) seems to provide no reproductive assurance and can cause severe seed and pollen discounting. The potential for selfing is greatest in species with a massive floral display such as $P$. schiedeanus, because having many flowers promotes the transfer of self-pollen to other flowers on the same genetic individual. Although geitonogamy is functionally cross-pollination involving a pollinating agent, genetically it is similar to autogamy since the pollen grains come from the same plant. The striking variation among individuals in the size of their floral display and the longevity of the flowers introduces problems for interpreting the relatively high fruit set value in P. schiedeanus after hand geitonogamous pollination. Given that the fruit size and fruit set values of geitonogamous and xenogamous hand-pollination were similar (38\% and $35 \%$, respectively; see Table 1) and higher than that under natural conditions (22\%), and that fruit set by self-pollination was relatively high (18\%), suggests that $P$. schiedeanus could produce all progeny by self-pollination. If so, geitonogamy may be a mechanism for reproductive assurance when flower visitation rates are low, particularly in cases in which plants are growing on host trees isolated from conspecifics. Several authors have suggested that geitonogamy leads to high rates of self-fertilization in self-compatible species, and reduces reproductive success in those that are self-incompatible (de Jong $e t$ al., 1993). Further observations on how pollination occurs in self-compatible $P$. schiedeanus are needed to determine how common geitonogamy is under natural conditions, and which floral visitors and foraging behaviors promote geitonogamous crosses. The extent of geitonogamous pollination under natural conditions undoubtedly varies a great deal within and between species, depending on factors such as daily flower number, plant density, flower longevity, nectar production patterns and pollinator behavior. When selfing requires pollinator visits (geitonogamy), allocation to attraction remains important for both selfed and outcrosses seed production (Lloyd, 1987). Thus, even at high selfing rates, species requiring pollinator visits for seed production are expected to devote considerable resources to attraction (Goodwillie et al., 2009). Although the cost of geitonogamous selfing can increase with an increase in display size and flower longevity (e.g. Ishi and Sakai, 2001), more work linking the evolution of mating strategies to the ecology of the floral displays is required to move the study of mating strategies beyond the outcrossing-selfing paradigm (Barrett, 2003).

\section{Acknowledgements}

We thank Oliva Cevallos and Irma Ruán for help in fieldwork. Comments by José Guadalupe García Franco and two anonymous reviewers greatly improved an earlier version of this paper. We were supported by a research grant (200501) from the fellowship graduate program of the Instituto de Ecología, A.C. and a doctoral scholarship (171228) granted by the Consejo Nacional de Ciencia y Tecnología (CONACyT-México) to M. M. Ramírez, and research funds (902- 12-563) from the Departamento de Biología Evolutiva, Instituto de Ecología, A.C. to J. F. Ornelas. This work constitutes partial fulfillment of M.M.R.'s doctorate in Ecología y Manejo de Recursos Naturales at the Instituto de Ecología, A.C.

\section{Literature cited}

Aizen M.A. 2005. Breeding system of Tristerix corymbosus (Loranthaceae), a winter-flowering mistletoe from the southern Andes. Australian Journal of Botany 53:357-361.

Azpeitia F. and Lara C. 2006. Reproductive biology and pollination of the parasitic plant Psittacanthus calyculatus (Loranthaceae) in Central Mexico. Journal of the Torrey Botanical Society 133:429-438.

Barrett S.C.H. 2003. Mating strategies in flowering plants: the outcrossing-selfing paradigm and beyond. Philosophical Transactions of the Royal Society of London B 358:991-1004.

Bolten A.B., Feinsinger P., Baker H.G. and Baker I. 1979. On the calculation of sugar concentration in flower nectar. Oecologia 41:301-304.

Burger W. and Kuijt J. 1983. Loranthaceae sensu lato. In Burger W. Ed. Flora Costarricensis, pp. 29-79, Feldiana Botany, New Series 13, Publication 1350, Field Museum of Natural History, Chicago.

Cházaro M. and Oliva R. 1988. Loranthaceae del centro de Veracruz y zona limítrofe de Puebla, IV. Cactáceas y Suculentas Mexicanas 33:42-48.

Cruden R.W., Hermann S.M. and Peterson S. 1983. Patterns of nectar production and plant animal coevolution. In Bentley B. and Elias T. Eds. The biology of nectaries, pp. 126-152, Columbia University Press, New York.

Goodwillie C., Sargent R.D., Eckert C.G., Elle E., Geber M.A., Johnston M.O., Kalisz S., Moeller D.A., Ree R.H., VallejoMarin M. and Winn A.A. 2009. Correlated evolution of mating system and floral display traits in flowering plants and its implications for the distribution of mating system variation. New Phytologist 185:311-321.

Hernández-Conrique D., Ornelas J.F., García-Franco J.G. and Vargas C.F. 2007. Nectar production of Calliandra longipedicellata (Fabaceae: Mimosoideae), an endemic Mexican shrub with multiple potential pollinators. Biotropica 39:459-467.

Ishi H.S. and Sakai S. 2001. Implications of geitonogamous pollination for floral longevity in Iris gracilipes. Functional Ecology 15:633-641.

Kearns C.A. and Inouye D.W. 1993. Techniques for pollination biologists. University Press of Colorado, Niwot, Colorado.

Kuijt J. 1987. Novelties in Mesoamerican mistletoes (Lorantha- 
ceae and Viscaceae). Annals of the Missouri Botanical Garden 74:511-532.

Kuijt J. 2009. Monograph of Psittacanthus (Loranthaceae). Systematic Botany Monographs Vol. 86. American Society of Plant Taxonomists, Ann Harbor.

Ladley J.J. and Kelly D. 1995. Explosive New Zealand mistletoe. Nature 378:766.

Ladley J.J., Kelly D. and Robertson A.W. 1997. Explosive flowering, nectar production, breeding systems and pollinators of New Zealand mistletoes (Loranthaceae). New Zealand Journal of Botany 35:345-360.

Lara C. and Ornelas J.F. 2002. Flower mites and nectar production in six hummingbird-pollinated plants with contrasting flower longevities. Canadian Journal of Botany 80:1216-1229.

Lara C. and Ornelas J.F. 2003. Hummingbirds as vectors of fungal spores in Moussonia deppeana (Gesneriaceae): Taking advantage from a mutualism? American Journal of Botany 90:260267.

Lara C. and Ornelas J.F. 2008. Pollination ecology of Penstemon roseus (Plantaginaceae), an endemic perennial shifted toward hummingbird specialization? Plant Systematics and Evolution 271:223-237.

Lloyd D.G. 1987. Allocations to pollen, seeds and pollination mechanisms in self-fertilizing plants. Functional Ecology 1:8389.

López de Buen L. and Ornelas J.F. 1999. Frugivorous birds, host selection and the mistletoe Psittacanthus schiedeanus, in central Veracruz, Mexico. Journal of Tropical Ecology 15:329-340.

López de Buen L. and Ornelas J.F. 2001. Seed dispersal of the mistletoe Psittacanthus schiedeanus by birds in central Veracruz, Mexico. Biotropica 33:487-494.

López de Buen L. and Ornelas J.F. 2002. Host compatibility of the cloud forest mistletoe Psittacanthus schiedeanus (Loranthaceae) in central Veracruz, Mexico. American Journal of Botany 89:95-102.

López de Buen L., Ornelas J.F. and García-Franco J.G. 2002. Mistletoe infection of trees located at fragmented forest edges in the cloud forests of central Veracruz, Mexico. Forest Ecology and Management 164:293-302.

Mathisen R.L., Daugherty C.M., Howell B.E., Melgar J.C. and
Sesnie S.E. 2007. New morphological measurements for Psittacanthus angustifolius and Psittacanthus pinicola (Loranthaceae). Madroño 33:156-163.

Mathiasen R.L., Nickrent D.L., Shaw D.C. and Watson D.M. 2008. Mistletoes: Pathology, systematics, ecology, and management. Plant Disease 92:988-1006.

Opler P.A. 1983. Nectar production in a tropical ecosystem. In Bentley B. and Elias T. Eds. The Biology of Nectaries, pp. 3079, Columbia University Press, New York.

Ordano M. and Ornelas J.F. 2004. Generous-like flowers: nectar production in two epiphytic bromeliads and a meta-analysis of removal effects. Oecologia 140:495-505.

Ornelas J.F., González C., Jiménez L., Lara C. and Martínez A.J. 2004. Reproductive ecology of distylous Palicourea padifolia (Rubiaceae) in a tropical montane cloud forest. II. Attracting and rewarding mutualistic and antagonistic visitors. American Journal of Botany 91:1061-1069.

Ornelas J.F., Ordano M., de-Nova A., Quintero M.E. and Garland T. 2007. Phylogenetic analysis of interspecific variation in nectar of hummingbird-visited plants. Journal of Evolutionary Biology 20:1904-1917,

Ramírez M.M. and Ornelas J.F. 2009. Germination of Psittacanthus schiedeanus (mistletoe) seeds after passage through the gut of Cedar Waxwings and Grey Silky-Flycatchers. Journal of the Torrey Botanical Society 136:322-331.

Stiles F.G. and Freeman C.E. 1993. Patterns in floral nectar characteristics of some bird-visited plant species from Costa Rica. Biotropica 25:191-205.

Tadey M. and Aizen M.A. 2001. Why do flowers of a hummingbird-pollinated mistletoe face down? Functional Ecology 15:782-790.

Vázquez-Collazo T. and Geils B.W. 2002. Psittacanthus in Mexico. In: Geils B.W., Cibrián-Tovar J. and Moody B. Eds. Mistletoes of North American Conifers, pp. 9-17, Gen. Tech. Rep. RMRS-GTR-98. U.S. Department of Agriculture, Forest Service, Rocky Mountain Research Station, Ogden.

Watson D.M. 2001. Mistletoe-a keystone resource in forests and woodlands worldwide. Annual Review in Ecology and Systematics 32:219-249.

Received: August 11, 2010

Accepted: October 27, 2010 